\title{
Erratum to: Deposition of atmospheric pollutant and their chemical characterization in snow pit profile at Dokriani Glacier, Central Himalaya
}

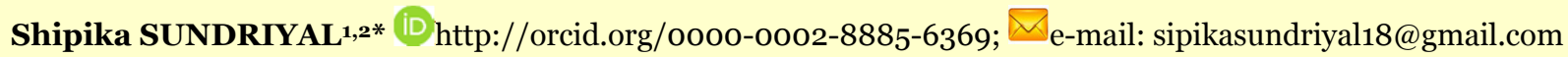 \\ Tanuj SHUKLA ${ }^{1,3}$ iD http://orcid.org/oooo-0002-9874-1282; e-mail: tanujshukla.geooo1@gmail.com \\ Lekhendra TRIPATHEE4 iD http://orcid.org/oooo-0oo1-6210-5105; e-mail: lekhendra.t@gmail.com \\ Dwarika Prashad DOBHAL1 iD http://orcid.org/oooo-0oo3-0537-6130; e-mail: dpdobhal@wihg.res.in \\ Sameer Kumar TIWARI5 iD http://orcid.org/o0oo-0002-7140-7778; e-mail: stiwariisr@gmail.com \\ Uday BHAN6 iD http://orcid.org/oooo-ooo1-7962-1202; e-mail: ubhan@ddn.upes.ac.in \\ *Corresponding author \\ 1 Centre for Glaciology, Wadia Institute of Himalayan Geology, Dehradun-2480o1, Uttarakhand, India \\ 2 National Institute of Hydrology, Roorkee-247667, Uttarakhand, India \\ 3 Indian Institute of Technology, Kanpur-208016, Uttar Pradesh, India \\ 4 State Key Laboratory of Cryospheric Science, Northwest Institute of Eco-Environment and Resources, Chinese \\ Academy of Sciences, Lanzhou,730ooo, China \\ 5 Wadia Institute of Himalayan Geology, Dehradun-2480o1, Uttarakhand, India \\ 6 University of Petroleum and Energy Studies, Bidholi, Dehradun-248oo1, Uttarakhand, India
}

Citation: Sundriyal S, Shukla T, Tripathee L, et al. (2019) Erratum to: Deposition of atmospheric pollutant and their chemical characterization in snow pit profile at Dokriani Glacier, Central Himalaya. Journal of Mountain Science 16(1). https://doi.org/10.1007/s11629-018-5341-3

(C) Science Press, Institute of Mountain Hazards and Environment, CAS and Springer-Verlag GmbH Germany, part of Springer Nature 2019

Erratum to: J. Mt. Sci. (2018) 15(10): 2236-2246

https://doi.org/10.1007/s11629-017-4817-x

The e-mail of the 5th author (sktiwari@gmail.com) is incorrect in the original article. It should be corrected into: stiwariisr@gmail.com. The ORCID of the 4th author (http://orcid.org/oooo-0002-9528-7697) is incorrect. It should be corrected into http://orcid.org/o0oo-0003-0537-6130.

The online version of the original article can be found at https://doi.org/10.1007/s11629-017-4817-x. 